\title{
Mechanism and Kinetic Analysis of Degradation of Atrazine by US/PMS
}

\author{
Yixin Lu ${ }^{1,2,3}$, Wenlai $\mathrm{Xu}^{4,5, *}$, Haisong Nie ${ }^{6, * \mathbb{D}}$, Ying Zhang ${ }^{1}$, Na Deng ${ }^{1}$ and Jianqiang Zhang ${ }^{3}$ \\ 1 College of Architectural and Environmental Engineering, Chengdu Technological University, \\ Chengdu 611730, China; yxlu61@163.com (Y.L.); txgsfy@163.com (Y.Z.); nstxdy@163.com (N.D.) \\ 2 Center of Big Data for Smart Environmental Protection, Chengdu Technological University, Chengdu 611730, \\ China \\ 3 Faculty of Geosciences and Environmental Engineering, Southwest Jiaotong University, Chengdu 610031, \\ China; zhangchengdu@126.com \\ 4 State Key Laboratory of Geohazard Prevention and Geoenvironment Protection, Chengdu University of \\ Technology, Chengdu 611730, China \\ 5 Haitian Water Grp Co Ltd., Chengdu 610059, China \\ 6 Department of International Environmental and Agricultural Science, Tokyo University of Agriculture and \\ Technology, Tokyo 1838509, Japan; nie-hs@cc.tuat.ac.jp \\ * Correspondence: xuwenlai1983@163.com (W.X.); nie-hs@cc.tuat.ac.jp (H.N.); Tel.: +86-135-5102-9646 (W.X.)
}

Received: 23 March 2019; Accepted: 16 May 2019; Published: 20 May 2019

\begin{abstract}
The degradation effect, degradation mechanism, oxidation kinetics, and degradation products of Atrazine (ATZ) by Ultrasound/Peroxymonosulfate (US/PMS) in phosphate buffer (PB) under different conditions were studied. It turned out that the degradation rate of US/PMS to ATZ was $45.85 \%$ when the temperature of the reaction system, concentration of PMS, concentration of ATZ, ultrasonic intensity, and reaction time were $20^{\circ} \mathrm{C}, 200 \mu \mathrm{mol} / \mathrm{L}, 1.25 \mu \mathrm{mol} / \mathrm{L}, 0.88 \mathrm{~W} / \mathrm{mL}$, and $60 \mathrm{~min}$, respectively. Mechanism analysis showed that PB alone had no degradation effect on ATZ while PMS alone had extremely weak degradation effect on ATZ. HO• and $\mathrm{SO}_{4}{ }^{-} \bullet$ coexist in the US/PMS system, and the degradation of ATZ at pH7 is dominated by free radical degradation. Inorganic anion experiments revealed that $\mathrm{Cl}^{-}, \mathrm{HCO}_{3}{ }^{-}$, and $\mathrm{NO}_{3}{ }^{-}$showed inhibitory effects on the degradation of ATZ by US/PMS, with $\mathrm{Cl}^{-}$contributing the strongest inhibitory effect while $\mathrm{NO}_{3}{ }^{-}$showed the weakest suppression effect. According to the kinetic analysis, the degradation kinetics of ATZ by US/PMS was in line with the quasi-first-order reaction kinetics. ETA with concentration of $1 \mathrm{mmol} / \mathrm{L}$ reduced the degradation rate of ATZ by US/PMS to 10.91\%. Product analysis indicated that the degradation of ATZ by US/PMS was mainly achieved by dealkylation, dichlorination, and hydroxylation, but the triazine ring was not degraded. A total of 10 kinds of ATZ degradation intermediates were found in this experiment.
\end{abstract}

Keywords: ultrasound; peroxymonosulfate; free radicals; ATZ; degradation mechanism

\section{Introduction}

Atrazine (ATZ) is one of the most widely used chemical herbicides in Asian and South American countries. The domestic use amount of ATZ was about $1.8 \times 10^{6} \mathrm{~kg}$ in late $1990 \mathrm{~s}$ and increased by an average of $20 \%$ each year [1]. At this level, the annual use amount of ATZ in China could reach $10^{8} \mathrm{~kg}$ by the end of 2018. ATZ can transform through different environmental media by diffuse, volatile, surface runoff, leaching, dry and wet deposition, etc. The ways ATZ entering water mainly include surface runoff, leaching, and dry and wet deposition [2]. The structure of ATZ is stable and difficult to degrade in the natural environment, and it is also hard to mineralize by microorganisms [3]. Its half-life in surface water can be up to 700 days [4]. ATZ with concentration up to $108 \mu \mathrm{g} / \mathrm{L}$ has been 
detected in north American rivers [5]. ATZ with a concentration of 3.9-81.3 $\mu \mathrm{g} / \mathrm{L}$ has been detected in many rivers and reservoirs in China [6-10], which far exceeded the limit of $2 \mu \mathrm{g} / \mathrm{L}$ according to the hygienic standard of drinking water in China.

The main effects of ATZ on biology are toxic effects and endocrine interference. According to the research by Benjamin [11], ATZ can cause stunted vertebrae development of zebra fish, and excessive ATZ (more than $3 \mathrm{mmol} / \mathrm{L}$ ) can cause serious defects in the craniofacial development of zebrafish. The research conducted by HAYES [12] and others found that, when the growth of the African tree frog from larva to adult are exposed to the ATZ solution with the concentration of $0.1 \mu \mathrm{g} / \mathrm{L}, 20 \%$ of the young frogs will develop into hermaphrodites, which indicates that ATZ with a low concentration can feminize the male African tree frog. The team of Jia [13] indicated that ATZ can further cause heart and liver damage in quails by causing ion disturbances. Meanwhile, the study by Sanderson [14] and others discovered that ATZ can interfere with endocrine balance by increasing the activity of the CYP19 enzyme in the human body.

Environmental atrazine removal mainly involves several kinds of methods including biodegradation, chemical degradation, and physical absorption. Ma et al. [15] reported that an Ensifer sp. strain can mineralize atrazine completely from the surrounding environment by utilizing it as its main nitrogen source. He et al. [16] reported the effects of fulvic acids and electrolytes on colloidal stability and photocatalysis of nano- $-\mathrm{TiO}_{2}$ for atrazine removal. The results indicate that the removal efficiency of atrazine by nano-TiO2 decreased with the increase in fulvic acids concentration. Wu et al. [17] investigated the removal efficiency of atrazine from aqueous solutions using magnetic Saccharomyces cerevisiae bio-nanomaterial, and found that the maximum removal efficiency of $100 \%$ was achieved at $28{ }^{\circ} \mathrm{C}$, a pH of 7.0 , and $150 \mathrm{rpm}$ with an initial atrazine concentration of $2.0 \mathrm{mg} / \mathrm{L}$. In another research, Zhu et al. [18] pointed out that both adsorption and biodegradation by the bio-nanocomposite contributed to atrazine removal. Zhao et al. [19] studied the sorption properties of biochars (CS450 and ADPCS450) from corn straw with different pretreatment and sorption behavior of atrazine. The sorption experiment showed that sorption was more favorable for atrazine sorption in acidic solution and the sorption was temperature-dependent and a spontaneous process. At present, the photo-Fenton and photo-Fenton-like advanced oxidation technologies based on Persulfate/Peroxymonosulfate (PS/PMS) have been proven to be effective in the degradation of ATZ in water including Heat/PS [20], PBS/PMS [21], UV/PS [22], and UV/PMS [23]. For example, Ji et al. [20] demonstrated that heat-activated persulfate could effectively degrade ATZ in water and pointed out that the increase of the persulfate concentration or temperature significantly enhanced the degradation efficiency. Khan et al. investigated the efficacy of atrazine degradation by UV, $\mathrm{UV} / \mathrm{H}_{2} \mathrm{O}_{2}$, UV/PS, and UV/PMS. However, so far, there have been few reports on the degradation of ATZ by US/PMS. Therefore, in this paper, the effect of US/PMS oxidative degradation to ATZ under different conditions was investigated in PB solution, and its degradation mechanism, oxidation kinetics, and degradation products were analyzed and discussed. These factors have a certain reference value for chemical treatment of pesticide wastewater.

\section{Materials and Methods}

\subsection{Reagents and Instruments}

Reagents: methyl alcohol of chromatographically pure, sodium hydroxide, sodium dihydrogen phosphate, sodium nitrite, ethanol, tert-butanol, sodium chloride, sodium bicarbonate, potassium nitrate, which are all analytically pure. ATZ and PMS ( $\mathrm{KHSO}_{5} \cdot 0.5 \mathrm{KHSO}_{4} \cdot 0.5 \mathrm{~K}_{2} \mathrm{SO}_{4}, \mathrm{KHSO}_{5} \geq 47 \%$ ) were purchased from Aladdin Co., Ltd. (Seoul, Korea).

Instruments: high performance liquid chromatograph (Waters 2695-2996), electronic scales, ultrasonic generator with a frequency of $150 \mathrm{KHz}$, lab pH meter from Shanghai Electronics Science Instrument Co., Ltd., Shang Hai, China, NC ultrasonic cleaner (KH5200DB), Ultra-pure Water Purifier 
from ULUPURE Co., Ltd., Chengdu, China, energy-saving intelligent thermostat tank (DC-1030), stirring hot plate (78 HW-1).

\subsection{Experimental Scheme}

\subsubsection{Solution Preparation}

Ultrapure water with the electrical resistivity of $18.24 \mathrm{M} \Omega \cdot \mathrm{cm}$ was used to prepare ATZ mother liquor of $100 \mu \mathrm{mol} / \mathrm{L}, \mathrm{NaH}_{2} \mathrm{PO}_{4}$ solution of $0.2 \mathrm{~mol} / \mathrm{L}, \mathrm{NaOH}$ solution of $0.02 \mathrm{~mol} / \mathrm{L}, \mathrm{NaNO}_{2}$ solution of $0.1 \mathrm{~mol} / \mathrm{L}, \mathrm{NaCl}$ solution of $1 \mathrm{~mol} / \mathrm{L}, \mathrm{NaHCO}_{3}$ solution of $0.5 \mathrm{~mol} / \mathrm{L}, \mathrm{KNO}_{3}$ solution of $1 \mathrm{~mol} / \mathrm{L}$, PMS solution of $0.01 \mathrm{~mol} / \mathrm{L}$ in sealed containers out of light, tertiary butanol solution of $16 \mathrm{~g} / \mathrm{L}$, and ethanol solution of $16 \mathrm{~g} / \mathrm{L}$. The preparation methods of phosphate buffer at $\mathrm{pH} 6, \mathrm{pH} 7$, and $\mathrm{pH} 8$ with constant volume of $1 \mathrm{~L}$ were shown in Table 1.

Table 1. The preparation method of $\mathrm{NaH}_{2} \mathrm{PO}_{4}-\mathrm{NaOH}$ buffer.

\begin{tabular}{ccc}
\hline $\mathrm{pH}$ & $\mathbf{0 . 2} \mathbf{~ m o l} / \mathbf{L ~} \mathbf{~ a H}_{\mathbf{2}} \mathbf{P O}_{\mathbf{4}} \mathbf{( m L )}$ & $\mathbf{0 . 2} \mathbf{~ m o l} / \mathbf{L ~} \mathbf{~ a O H}(\mathbf{m L})$ \\
\hline 6 & 250 & 28.50 \\
7 & 250 & 148.15 \\
8 & 250 & 244.00 \\
\hline
\end{tabular}

\subsubsection{Experimental Scheme of ATZ Degradation by US/PMS}

The degradation efficiency of US/PMS to ATZ in $1.25 \mathrm{mmol} / \mathrm{L}$ phosphate buffered solution was investigated under the following conditions: different temperature of $10,15,20$, and $25^{\circ} \mathrm{C}$, different $\mathrm{pH}$ value of 6,7 , and 8 , different PMS concentration of 50, 100, 200, and $400 \mu \mathrm{mol} / \mathrm{L}$, different ATZ concentration of $0.625,1.25$, and $2.5 \mu \mathrm{mol} / \mathrm{L}$, and different US intensity with the frequency of $150 \mathrm{KHz}$ of $0.22 \mathrm{~W} / \mathrm{mL}, 0.44 \mathrm{~W} / \mathrm{mL}, 0.66 \mathrm{~W} / \mathrm{mL}$, and $0.88 \mathrm{~W} / \mathrm{mL}$.

Different concentrations of tertiary butanol and ethanol were added to investigate the mechanism of degradation of ATZ by US/PMS in $20^{\circ} \mathrm{C}$ water bath when the US intensity, PB concentration, PMS concentration, and ATZ concentration were $0.88 \mathrm{~W} / \mathrm{mL}, 1.25 \mathrm{mmol} / \mathrm{L}, 200 \mu \mathrm{mol} / \mathrm{L}$, and $1.25 \mu \mathrm{mol} / \mathrm{L}$, respectively. The effect of common anions in water including $\mathrm{Cl}^{-}, \mathrm{HCO}_{3}{ }^{-}$, and $\mathrm{NO}_{3}{ }^{-}$on US/PMS degradation to ATZ was investigated by adding different concentrations of $\mathrm{NaCl}, \mathrm{NaHCO}_{3}$, and $\mathrm{NaNO}_{3}$ solution. $\mathrm{NaNO}_{2}$ solution of $0.1 \mathrm{~mol} / \mathrm{L}$ served as the termination agent for the reaction.

\subsection{Analytical Method}

Symmetry ${ }^{\circledR} \mathrm{C} 18$ stable bond was adopted to detect ATZ, and the specific test method is as follows: the mobile phase ratio of methyl alcohol to ultrapure water is $60: 40$, flow velocity of $0.8 \mathrm{~mL} / \mathrm{min}$, column temperature of $40^{\circ} \mathrm{C}$, and wavelength of $225 \mathrm{~nm}$.

\section{Results and Discussion}

\subsection{Effect of Temperature on ATZ Degradation by US/PMS}

The influence of temperature on ATZ degradation by US/PMS in phosphate buffered solution at $\mathrm{pH} 7$ was shown in Figure 1 when the concentration of ATZ, US intensity, and PMS concentration were respectively $1.25 \mu \mathrm{mol} / \mathrm{L}, 0.88 \mathrm{~W} / \mathrm{mL}$, and $200 \mu \mathrm{mol} / \mathrm{L}$. In this figure and all the following figures, $C$ represents ATZ concentration at any time and $C_{0}$ is the concentration of ATZ at time 0 . According to Figure 1, with the increase of reaction temperature, the effect of ATZ degradation by US/PMS was enhanced. The ATZ removal rate increased from $19.37 \%$ to $50.96 \%$ when the reaction temperature rose from $10{ }^{\circ} \mathrm{C}$ to $25{ }^{\circ} \mathrm{C}$. This is mainly due to the increase in the percentage of PMS molecules activated by a temperature rise, which accelerates the decomposition of PMS to generate $\mathrm{SO}_{4}{ }^{-} \bullet$ and $\mathrm{HO} \bullet$ [24]. At the same time, increasing the temperature will accelerate the motion speed of molecules and increasing the collision frequency between $\mathrm{ATZ}, \mathrm{SO}_{4}^{-} \bullet$, and $\mathrm{HO} \bullet$, accelerates the degradation of 
ATZ. It is easy to observe that, when the temperature increased from $15^{\circ} \mathrm{C}$ to $20^{\circ} \mathrm{C}$, the removal rate of ATZ increased more significantly. When compared with the temperature from $10{ }^{\circ} \mathrm{C}$ to $15^{\circ} \mathrm{C}$ and from $20{ }^{\circ} \mathrm{C}$ to $25^{\circ} \mathrm{C}$, the improvement effect clearly indicates that the temperature change within the normal range has a great impact on US/PMS degradation to ATZ. As the reaction temperature increases, the effect of temperature variation on the US/PMS based removal rate of ATZ will be less pronounced. $\mathrm{Su}$ et al. also observed the same phenomenon [25] in the research of the degradation efficiency of the antibiotics amoxicillin in aqueous solution. They found that the activation of sulphate radicals under ultrasound irradiation present nonlinear correlation with a temperature variation.

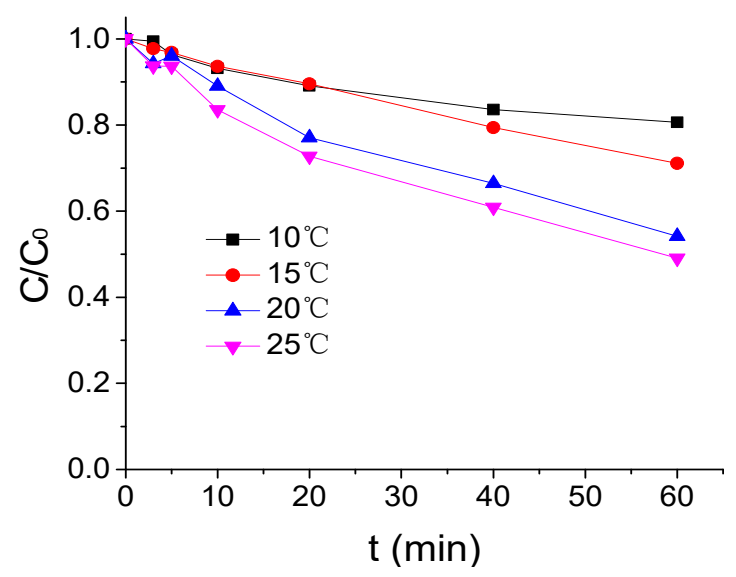

Figure 1. The ATZ removal rate under a different temperature $\left(C_{0}=1.25 \mu \mathrm{mol} / \mathrm{L}\right)$.

\subsection{The Effect of PMS Concentration on the ATZ Degradation by US/PMS}

The influence of PMS concentration on the ATZ degradation by US/PMS was demonstrated in Figure 2 when the ATZ concentration, US intensity, and temperature were $1.25 \mu \mathrm{mol} / \mathrm{L}, 0.88 \mathrm{~W} / \mathrm{mL}$, and $20^{\circ} \mathrm{C}$. As shown in Figure 2, the effect of ATZ degradation by US/PMS was enhanced with the increase of PMS concentration. The ATZ removal rate increased from $28.90 \%$ to $58.77 \%$ when the PMS concentration rose from $50 \mu \mathrm{mol} / \mathrm{L}$ to $400 \mu \mathrm{mol} / \mathrm{L}$. It is vital because increasing PMS concentration in the reaction system will relatively increase the yield of $\mathrm{SO}_{4}{ }^{-} \bullet$ and $\mathrm{HO} \bullet$ per unit time, and then accelerate ATZ degradation by US/PMS when other conditions remain unchanged. It is worth mentioning that, when the concentration of PMS increased from $100 \mu \mathrm{mol} / \mathrm{L}$ to $200 \mu \mathrm{mol} / \mathrm{L}$, the removal rate of ATZ did not change much. Therefore, PMS concentration has a greater influence on US/PMS degradation to ATZ.

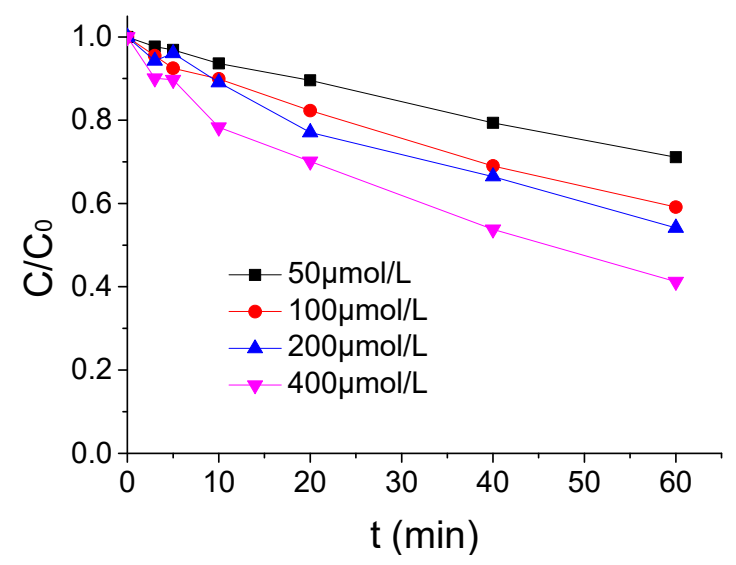

Figure 2. The ATZ removal rates under a different PMS density $\left(C_{0}=1.25 \mu \mathrm{mol} / \mathrm{L}\right)$. 


\subsection{The Effect of $p H$ Value on the ATZ Degradation by US/PMS}

The impact results of a different $\mathrm{pH}$ value on the ATZ degradation by US/PMS in phosphate buffer solution at $20{ }^{\circ} \mathrm{C}$ were shown in Figure 3 when the concentration of ATZ. US intensity and PMS concentration were $1.25 \mu \mathrm{mol} / \mathrm{L}, 0.88 \mathrm{~W} / \mathrm{mL}$, and $200 \mu \mathrm{mol} / \mathrm{L}$. From Figure 3 , the effect of ATZ degradation by US/PMS was enhanced with the increase of $\mathrm{pH}$ value. The ATZ removal rate increased from $46.46 \%$ to $56.77 \%$ when the $\mathrm{pH}$ value rose from 6 to 8 . The ATZ removal rate was higher in alkaline $\mathrm{pH}$ than in acidic $\mathrm{pH}$, primarily because ultrasound can stimulate PMS to generate $\mathrm{SO}_{4}{ }^{-} \bullet$ and $\mathrm{HO} \bullet$ simultaneously (Equation (1) shows the reaction equation), and $\mathrm{HO} \bullet$ has a slightly stronger oxidation capacity to ATZ than $\mathrm{SO}_{4}^{-} \bullet$. The secondary reaction rates of the two with ATZ were $3 \times 10^{9} \mathrm{M}^{-1} \cdot \mathrm{s}^{-1}$ [26] and $2.59 \times 10^{9} \mathrm{M}^{-1} \cdot \mathrm{s}^{-1}$ [23], respectively. In aqueous solution, $\mathrm{SO}_{4}^{-} \bullet$ can react with water at any given $\mathrm{pH}$ condition to produce $\mathrm{HO \bullet}$, and the reaction rate constant is $8.30 \mathrm{M}^{-1} \cdot \mathrm{s}^{-1}$ [27] (see Equation (2) for the reaction equation). Under alkaline conditions, $\mathrm{SO}_{4}{ }^{-} \bullet$ can also react with $\mathrm{OH}^{-}$to produce $\mathrm{HO} \bullet$, and the reaction rate constant is $6.50 \times 10^{7}$ [28] (The equation is shown in Equation (3)), and the change of $\mathrm{pH}$ did not affect the yield of the $\mathrm{SO}_{4}^{-} \bullet$ in US/PMS. Thus, under alkaline conditions, the US/PMS system produced more $\mathrm{HO} \bullet$ per unit time. Therefore, the removal rate of ATZ is higher in alkaline $\mathrm{pH}$ than in acidic conditions. Thus, it can be seen that $\mathrm{pH}$ has a greater influence on ATZ degradation by US/PMS [23,26,28].

$$
\begin{gathered}
\mathrm{HSO}_{5}{ }^{-}+\mathrm{US} \rightarrow \mathrm{SO}_{4}{ }^{-} \bullet+\mathrm{HO} \bullet \mathrm{K}_{\mathrm{HO} \bullet}=3 \times 10^{9} \mathrm{M}^{-1} \cdot \mathrm{s}^{-1} ; \mathrm{KSO}^{-} \bullet=2.59 \times 10^{9} \mathrm{M}^{-1} \cdot \mathrm{s}^{-1} \\
\mathrm{SO}_{4}{ }^{-} \bullet+\mathrm{H}_{2} \mathrm{O} \rightarrow \mathrm{SO}_{4}{ }^{2-}+\mathrm{HO} \bullet+\mathrm{H}^{+} \mathrm{K}=8.30 \mathrm{M}^{-1} \cdot \mathrm{s}^{-1} \\
\mathrm{SO}_{4}{ }^{-} \bullet+\mathrm{OH}^{-} \rightarrow \mathrm{SO}_{4}{ }^{2-}+\mathrm{HO} \bullet \mathrm{K}=6.50 \times 10^{7}
\end{gathered}
$$

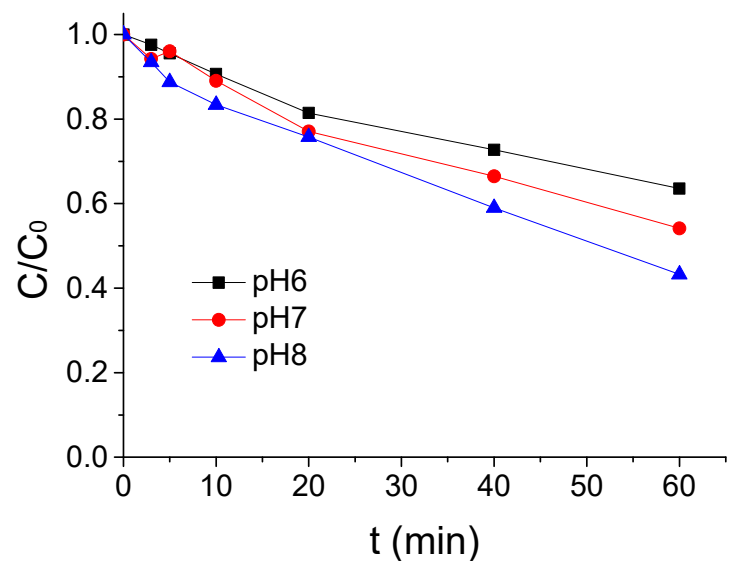

Figure 3. The ATZ removal rate under a different $\mathrm{pH}\left(C_{0}=1.25 \mu \mathrm{mol} / \mathrm{L}\right)$.

\subsection{The Effect of US Intensity on the ATZ Degradation by US/PMS}

The influence of different US intensity on the ATZ degradation by US/PMS in PB at $20^{\circ} \mathrm{C}$ were shown in Figure 4 when the ATZ concentration, PMS concentration, and $\mathrm{pH}$ were, respectively, $1.25 \mu \mathrm{mol} / \mathrm{L}, 200 \mu \mathrm{mol} / \mathrm{L}$, and $7 \mu \mathrm{mol} / \mathrm{L}$. As seen in Figure 4, the effect of US/PMS to ATZ degradation gradually increased with the increase of US intensity in the reaction system. The removal rate of ATZ increased from $25.53 \%$ to $45.85 \%$ when the US intensity increased from $0.22 \mathrm{~W} / \mathrm{mL}$ to $0.88 \mathrm{~W} / \mathrm{mL}$. This is mainly due to the fact that the ultrasound can cause a cavitation bubble phenomenon, while the formation and collapse of the cavitation bubble can form extreme high temperature and pressure conditions and then activate PMS to generate $\mathrm{SO}_{4}{ }^{-} \bullet$ and $\mathrm{HO} \bullet$ to degrade ATZ [25,29]. It is worth noting that, when the US intensity increased from $0.66 \mathrm{~W} / \mathrm{mL}$ to $0.88 \mathrm{~W} / \mathrm{mL}$, the removal rate of ATZ was significantly higher than when the US intensity increased from $0.22 \mathrm{~W} / \mathrm{mL}$ to $0.44 \mathrm{~W} / \mathrm{mL}$. The results showed that US intensity had a great effect on US/PMS degradation to ATZ. 


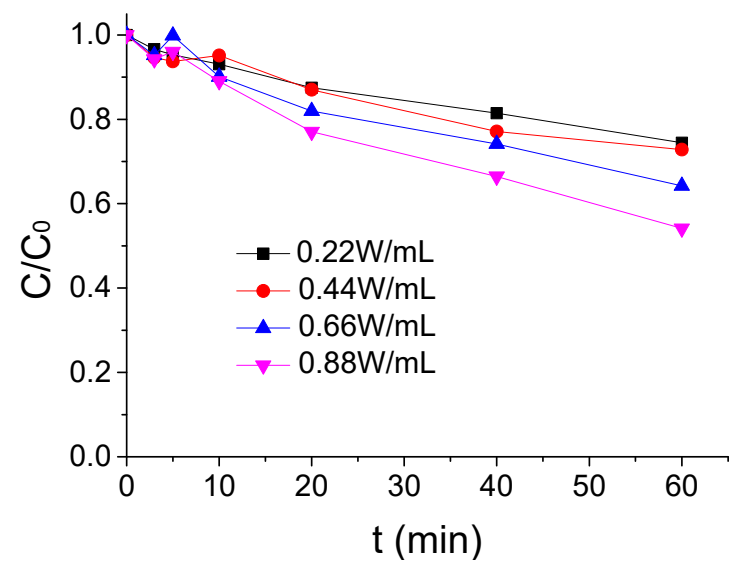

Figure 4. The ATZ removal rate under a different US intensity $\left(C_{0}=1.25 \mu \mathrm{mol} / \mathrm{L}\right)$.

\subsection{The Effect of ATZ Concentration on the ATZ Degradation by US/PMS}

The influence of different ATZ intensity on the ATZ degradation by US/PMS in PB at $20 \mu \mathrm{mol} / \mathrm{L}$ were shown in Figure 5 when the $\mathrm{pH}$, US intensity, and PMS concentration were, respectively, 7, $1.25 \mu \mathrm{mol} / \mathrm{L}, 0.88 \mathrm{~W} / \mathrm{mL}$, and $100 \mu \mathrm{mol} / \mathrm{L}$. From Figure 5, with the increase of ATZ concentration in the reaction system, the effect of US/PMS degradation ATZ was gradually weakened. The ATZ removal rate decreased from $71.37 \%$ to $35.22 \%$ when the ATZ concentration increased from $0.625 \mu \mathrm{mol} / \mathrm{L}$ to $2.5 \mu \mathrm{mol} / \mathrm{L}$. It is easy to observe that, when the ATZ concentration increased from $0.625 \mu \mathrm{mol} / \mathrm{L}$ to $1.25 \mu \mathrm{mol} / \mathrm{L}$, the ATZ removal rate decreased significantly from $71.37 \%$ to $40.88 \%$. The ATZ removal rate decreased slightly from $40.88 \%$ to $35.22 \%$ when the ATZ concentration increased from $1.25 \mu \mathrm{mol} / \mathrm{L}$ to $2.5 \mu \mathrm{mol} / \mathrm{L}$. The results showed that ATZ concentration had a significant effect on ATZ degradation by US/PMS.

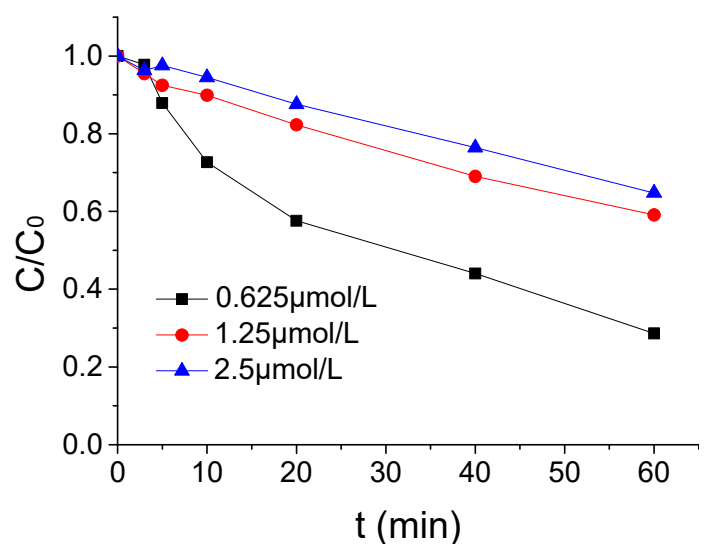

Figure 5. The ATZ removal rates under different ATZ density $C_{0}$.

\subsection{Mechanism Analysis of ATZ Degradation by US/PMS}

The mechanism of ATZ degradation by US/PMS was analyzed by using a single factor method, and the results are shown in Figure 6 where the concentration of PB in pH7, US intensity, PMS concentration, temperature, and ATZ concentration were $1.25 \mathrm{mmol} / \mathrm{L}, 0.88 \mathrm{~W} / \mathrm{mL}, 200 \mu \mathrm{mol} / \mathrm{L}, 20^{\circ} \mathrm{C}$, and $1.25 \mu \mathrm{mol} / \mathrm{L}$. According to Figure 6a, PB alone had no degradation effect on ATZ, but PMS alone had a very weak degradation effect on ATZ at the current concentration, and the degradation rate was $4.1 \%$. The degradation efficiency of ATZ by US/PB/PMS (The US/PB/PMS system and US/PMS system are distinguished in this section, and the US/PMS system in other places refers to PB) alone was $13.43 \%$, which accounts for $29.29 \%$ of the total removal rate of US degradation ATZ. The removal rate of ATZ by US/PMS was $45.85 \%$. When compared with US alone, the degradation efficiency of ATZ was 
$32.43 \%$ higher, mainly because US can stimulate PMS to generate $\mathrm{SO}_{4}{ }^{-} \bullet$ and $\mathrm{HO} \bullet$, and $\mathrm{SO}_{4}{ }^{-} \bullet-$ and $\mathrm{HO} \bullet$ have better degradation effects on ATZ [25,30]. Research by Dionysiou [31] indicated that the reaction rate of TBA to $\mathrm{HO} \bullet$ and $\mathrm{SO}_{4}-\bullet$ is $3.8-7.6 \times 10^{8} \mathrm{M}^{-1} \cdot \mathrm{s}^{-1}$ and $4-9.1 \times 10^{5} \mathrm{M}^{-1} \cdot \mathrm{s}^{-1}$, respectively. The experiment conducted by Buxton [32] showed that the reaction rate of ETA to $\mathrm{HO} \bullet$ and $\mathrm{SO}_{4}^{-} \bullet$ is $1.2-2.8 \times 10^{9} \mathrm{M}^{-1} \cdot \mathrm{s}^{-1}$ and 1.6-7.7 $\times 10^{7} \mathrm{M}^{-1} \cdot \mathrm{s}^{-1}$. Therefore, when $\mathrm{HO} \bullet$ and $\mathrm{SO}_{4}{ }^{-} \bullet$ coexist in the reaction system, $\mathrm{HO} \bullet$ can be captured by TBA, and $\mathrm{HO} \bullet$ and $\mathrm{SO}_{4}{ }^{-} \bullet$ by ETA. From Figure $6 \mathrm{~b}-\mathrm{d}$, both TBA and ETA can effectively inhibit the degradation of ATZ by US/PMS, and ETA has a stronger inhibitory effect than TBA. HO• and $\mathrm{SO}_{4}^{-} \bullet$ exist in the US system simultaneously. The degradation rate of US to ATZ decreased from $45.85 \%$ to $16.36 \%$ and $8.28 \%$, respectively, when $48 \mathrm{mg} / \mathrm{L} \mathrm{TBA}$ and $48 \mathrm{mg} / \mathrm{L}$ ETA were maintained in PB at a $\mathrm{pH}$ of 7 . Therefore, the degradation of ATZ by US/PMS at a $\mathrm{pH}$ of 7 was dominated by free radical oxidation.
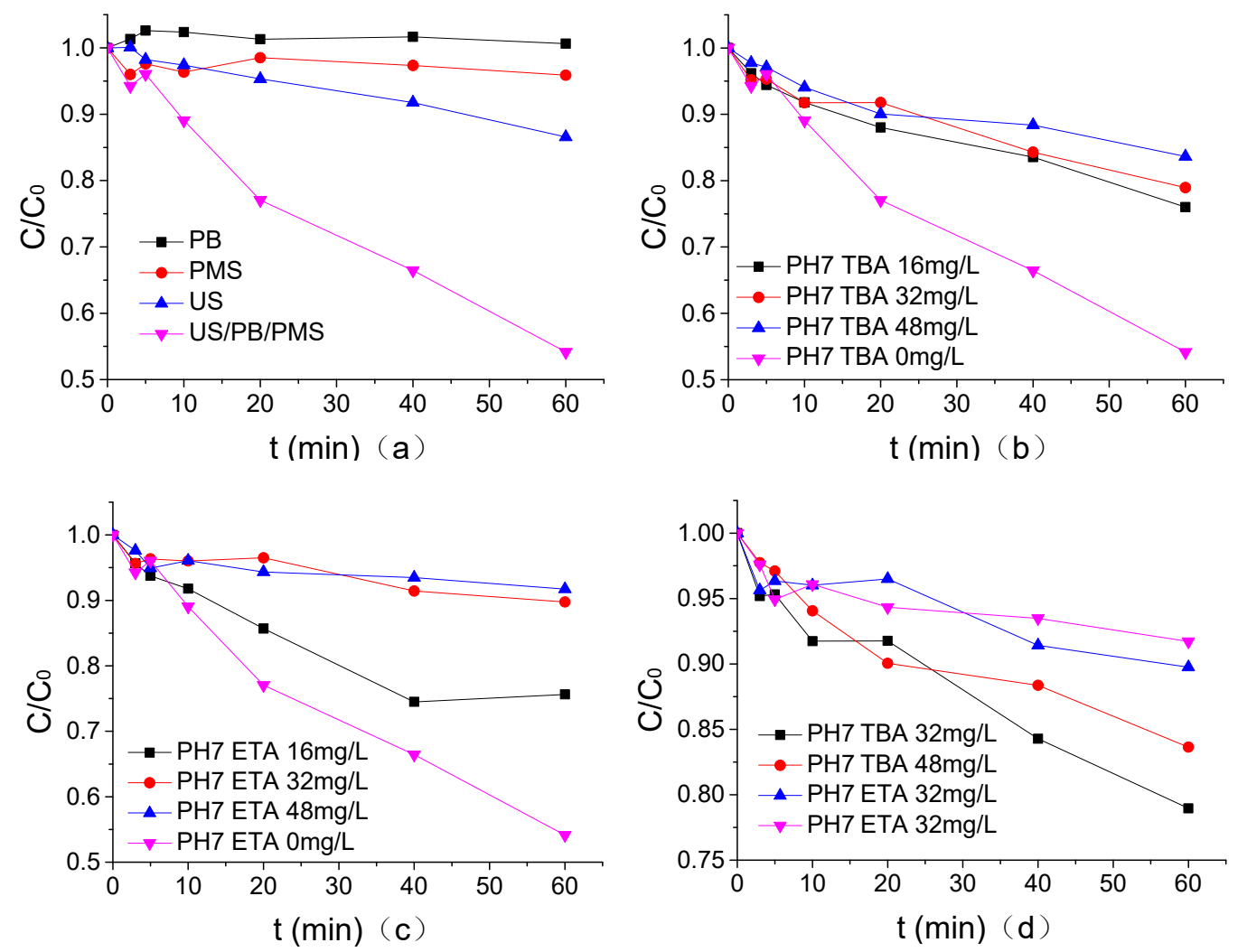

Figure 6. (a) The analysis of the oxidation effect of each component in the US/PMS system. (b) The effect of TBA on the degradation of ATZ by US/PMS in PB at pH 7. (c) The effect of ETA on the degradation of ATZ by US/PMS in PB at pH 7. (d) The Comparison of TBA and ETA on US/PMS degradation ATZ at a $\mathrm{pH}$ of 7 . The initial concentration of $C_{0}$ is $1.25 \mu \mathrm{mol} / \mathrm{L}$.

\subsection{Effect of Common Anion Concentration in Water on PMS Degradation of ATZ}

The influence of common anions in waters as $\mathrm{Cl}^{-}, \mathrm{HCO}_{3}{ }^{-}$, and $\mathrm{NO}_{3}{ }^{-}$on the degradation of ATZ by UV/PMS in PB of $1.25 \mathrm{mmol} / \mathrm{L}$ was shown in Figure 7 when the $\mathrm{pH}$ of PB, US intensity, PMS concentration, temperature, and ATZ concentration were $7,0.88 \mathrm{~W} / \mathrm{mL}, 200 \mu \mathrm{mol} / \mathrm{L}, 20^{\circ} \mathrm{C}$, and $1.25 \mu \mathrm{mol} / \mathrm{L}$, respectively. According to Figure $7, \mathrm{Cl}^{-}, \mathrm{HCO}_{3}{ }^{-}$, and $\mathrm{NO}_{3}{ }^{-}$with the same concentration showed an inhibitory effect on ATZ degradation by the US/PMS system. It is easy to observe that the inhibition ability of the three kinds of ions, from largest to smallest, is in the order of $\mathrm{Cl}^{-}, \mathrm{HCO}_{3}^{-}$, and $\mathrm{NO}_{3}{ }^{-}$. Specifically, the degradation efficiency of the three kinds of ions on ATZ is reduced from $45.85 \%$ to $23.72 \%, 34.93 \%$, and $46.75 \%$, respectively, after adding $0.1 \mathrm{mmol} / \mathrm{L} \mathrm{Cl}^{-}, \mathrm{HCO}_{3}{ }^{-}$, and $\mathrm{NO}_{3}{ }^{-}$ into the US/PMS system. The reaction rates of $\mathrm{Cl} \bullet, \mathrm{Cl}_{2}{ }^{-} \bullet, \mathrm{ClOH}^{-} \bullet$ and $\mathrm{CO}_{3}{ }^{-} \bullet$ with ATZ were lower than those of $\mathrm{HO} \bullet$ and $\mathrm{SO}_{4}{ }^{-} \bullet$ with ATZ. The inhibitory effect of $\mathrm{Cl}^{-}$was slightly stronger than that 
of $\mathrm{HCO}_{3}{ }^{-}$mainly because the secondary reaction constant between $\mathrm{Cl}_{2}{ }^{-} \bullet$ and $\mathrm{ATZ}$ was lower than that between $\mathrm{CO}_{3}{ }^{-} \bullet$ and ATZ. The weak inhibitory effect of the compound is mainly caused by the following two reasons: first, $\mathrm{NO}_{3}{ }^{-}$can react with $\mathrm{SO}_{4}{ }^{-} \bullet$ to form $\mathrm{NO}_{3} \bullet$ with a high redox potential, and $\mathrm{NO}_{3} \bullet$ can also participate in the degradation of the ATZ reaction. Second, objectively speaking, the concentration of $\mathrm{NO}_{3}{ }^{-}$is much higher than that of ATZ in the US/PMS system [33-35]. While the reaction rate of $\mathrm{NO}_{3}{ }^{-}$and $\mathrm{SO}_{4}{ }^{-} \bullet$ is very low, a large number of $\mathrm{NO}_{3}{ }^{-}$and $\mathrm{SO}_{4}{ }^{-} \bullet$ still compete with ATZ in the US/PMS system, which makes $\mathrm{NO}_{3}{ }^{-}$show weak inhibition on the macro level (the main equations are shown in Equations (4) to (15)) [23,26,27,36-43].

$$
\begin{aligned}
& \mathrm{HO} \bullet+\mathrm{HCO}_{3}{ }^{-} \rightarrow \mathrm{CO}_{3}{ }^{-} \bullet+\mathrm{H}_{2} \mathrm{OK}=8.60 \times 10^{6} \mathrm{M}^{-1} \cdot \mathrm{s}^{-1} \\
& \mathrm{SO}_{4}{ }^{-} \bullet+\mathrm{HCO}_{3}{ }^{-} \rightarrow \mathrm{CO}_{3}{ }^{-} \bullet+\mathrm{HSO}_{4}{ }^{-} \mathrm{K}=2.80 \times 10^{6} \mathrm{M}^{-1} \cdot \mathrm{s}^{-1} \\
& \mathrm{CO}_{3}{ }^{-} \bullet+\text { ATZ } \rightarrow \text { products } \mathrm{K}=6.20 \times 10^{6} \mathrm{M}^{-1} \cdot \mathrm{s}^{-1} \\
& \mathrm{HO} \bullet+\mathrm{Cl}^{-} \rightarrow \mathrm{ClOH}^{-} \bullet \mathrm{K}=4.30 \times 10^{9} \mathrm{M}^{-1} \cdot \mathrm{s}^{-1} \\
& \mathrm{ClOH}^{-} \bullet+\mathrm{Cl}^{-} \rightarrow \mathrm{Cl}_{2}{ }^{-} \bullet+\mathrm{OH}^{-} \mathrm{K}=1.0 \times 10^{5} \mathrm{M}^{-1} \cdot \mathrm{s}^{-1} \\
& \mathrm{SO}_{4}{ }^{-} \bullet+\mathrm{Cl}^{-} \rightarrow \mathrm{Cl} \bullet+\mathrm{SO}_{4}{ }^{2-} \mathrm{K}=3.0 \times 10^{9} \mathrm{M}^{-1} \cdot \mathrm{s}^{-1} \\
& \mathrm{Cl} \bullet+\mathrm{Cl}^{-} \rightarrow \mathrm{Cl}_{2}^{-} \bullet \mathrm{K}=8.50 \times 10^{9} \mathrm{M}^{-1} \cdot \mathrm{s}^{-1} \\
& \mathrm{Cl}_{2}{ }^{-} \bullet+\mathrm{ATZ} \rightarrow \text { products } \mathrm{K}=5.0 \times 10^{4} \mathrm{M}^{-1} \cdot \mathrm{s}^{-1} \\
& \mathrm{SO}_{4}{ }^{-} \bullet+\mathrm{NO}_{3}{ }^{-} \rightarrow \mathrm{NO}_{3} \bullet+\mathrm{SO}_{4}{ }^{2-} \mathrm{K}=5.0 \times 10^{4} \mathrm{M}^{-1} \cdot \mathrm{s}^{-1} \\
& \mathrm{NO}_{3} \bullet+\text { ATZ } \rightarrow \text { products } \\
& \mathrm{SO}_{4}{ }^{-} \bullet+\text { ATZ } \rightarrow \text { products } \mathrm{K}=2.59 \times 10^{9} \mathrm{M}^{-1} \cdot \mathrm{s}^{-1} \\
& \mathrm{HO} \bullet+\text { ATZ } \rightarrow \text { products } K=3.0 \times 10^{9} \mathrm{M}^{-1} \cdot \mathrm{s}^{-1}
\end{aligned}
$$
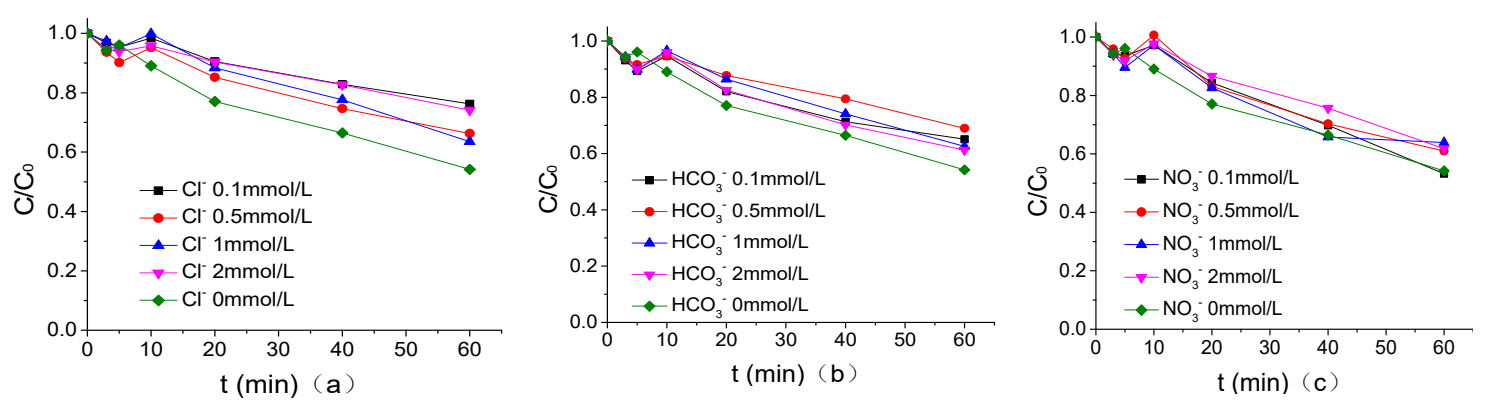

Figure 7. (a) The effect of $\mathrm{Cl}^{-}$on the degradation of ATZ by US/PMS in PB at pH 7. (b) The effect of $\mathrm{HCO}_{3}{ }^{-}$on the degradation of ATZ by US/PMS in $\mathrm{PB}$ at $\mathrm{pH}$ 7. (c) The effect of $\mathrm{NO}_{3}{ }^{-}$on the degradation of ATZ by US/PMS in PB at $\mathrm{pH}$ 7. The initial concentration $C_{0}=1.25 \mu \mathrm{mol} / \mathrm{L}$.

\subsection{Kinetic Analysis of ATZ Degradation by US/PMS}

According to the research of Simonin [44], the kinetic model of ATZ degradation by $\mathrm{O}_{3}$ was established according to the following kinetic equation, and the quasi first order kinetic equation is as follows:

$$
\operatorname{Ln}\left(C / C_{0}\right)=-K_{1} t
$$

C-ATZ concentration at any time, $\mu \mathrm{mol} / \mathrm{L}$;

$\mathrm{C}_{0}$-ATZ concentration at time $0, \mu \mathrm{mol} / \mathrm{L}$;

$K_{1}$ - quasi first order rate constant, $\mathrm{min}^{-1}$. 
In $\mathrm{PB}$ of $1.25 \mathrm{mmol} / \mathrm{L}$ at a $\mathrm{pH}$ of 7 , when the concentration of $\mathrm{Cl}^{-}, \mathrm{HCO}_{3}{ }^{-}, \mathrm{NO}_{3}{ }^{-}$, and ETA was $1.25 \mu \mathrm{mol} / \mathrm{L}$, the quasi first order reaction kinetics of ATZ degradation by US/PMS was fitted using $\operatorname{Ln}\left(C / C_{0}\right)(y)$ as the $\mathrm{Y}$-axis and $\mathrm{t}(\mathrm{x})$ as the $\mathrm{X}$-axis when the US intensity, PMS concentration, temperature, and ATZ concentration were respectively $0.88 \mathrm{~W} / \mathrm{mL}, 200 \mu \mathrm{mol} / \mathrm{L}, 20^{\circ} \mathrm{C}$, and $1.25 \mu \mathrm{mol} / \mathrm{L}$. Its dynamic fitting curves were shown in Figure 8 and the parameters for the quasi first order kinetic fitting equation were shown in Table 2. According to Figure 8 and Table 2, the ATZ degradation kinetics by US/PMS at different PMS concentrations were consistent with the quasi first order reaction kinetics, and ETA had the strongest inhibitory effect on the ATZ degradation of US/PMS under the same concentration. ETA reduced the degradation rate of US/PMS to ATZ by $10.91 \%$, and the inhibitory effect of $\mathrm{Cl}^{-}, \mathrm{HCO}_{3}^{-}$, and $\mathrm{NO}_{3}{ }^{-}$on ATZ degradation by US/PMS was not significantly different under the concentration of $1 \mathrm{mmol} / \mathrm{L}$. The mechanism of the three ion inhibitory effects is described in detail above and will not be described in this paper. Research results by Li and others [45] discovered that the degradation of 1,1,1-trichloroethane and 1,4-dioxane by US/PS were consistent with the first order reaction kinetics, which is similar to the results of this experiment.
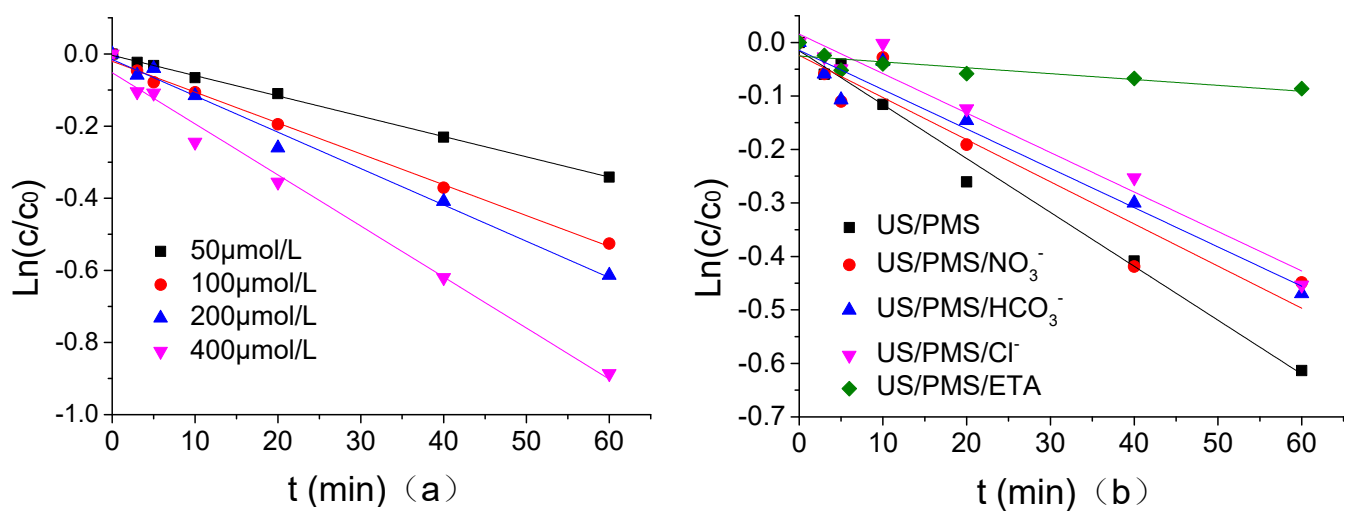

Figure 8. (a) The kinetics of quasi - first - order reaction of US/PMS degradation ATZ under different PMS density. (b) The kinetics of quasi - first - order reaction of US/PMS degradation ATZ under a different PMS density and different reaction systems. The initial concentration of $C_{0}$ is $1.25 \mu \mathrm{mol} / \mathrm{L}$.

Table 2. The kinetics parameters of US/PMS degradation ATZ.

\begin{tabular}{|c|c|c|c|}
\hline \multicolumn{2}{|c|}{ Reaction System } & $K_{1}\left(\min ^{-1}\right)$ & $R^{2}$ \\
\hline \multirow{4}{*}{ US/PMS } & $50 \mu \mathrm{mol} / \mathrm{L}$ & -0.00563 & 0.99875 \\
\hline & $100 \mu \mathrm{mol} / \mathrm{L}$ & -0.00856 & 0.99571 \\
\hline & $200 \mu \mathrm{mol} / \mathrm{L}$ & -0.01008 & 0.98788 \\
\hline & $400 \mu \mathrm{mol} / \mathrm{L}$ & -0.01415 & 0.98768 \\
\hline \multicolumn{2}{|c|}{$\mathrm{US} / \mathrm{PMS} / \mathrm{NO}_{3}^{-}$} & -0.00788 & 0.89850 \\
\hline \multicolumn{2}{|c|}{$\mathrm{US} / \mathrm{PMS} / \mathrm{HCO}_{3}^{-}$} & -0.00735 & 0.94938 \\
\hline \multicolumn{2}{|c|}{$\mathrm{US} / \mathrm{PMS} / \mathrm{Cl}^{-}$} & -0.00738 & 0.95685 \\
\hline \multicolumn{2}{|c|}{ US/PMS/ETA } & -0.00110 & 0.68884 \\
\hline
\end{tabular}

\subsection{Analysis of ATZ Degradation Products and Degradation Pathway by US/PMS}

The degradation products of ATZ by US/PMS were analyzed by HPLC-ESI-MS (cationic mode), and the degradation path was speculated. The three samples were extracted for 5, 20, and $60 \mathrm{~min}$ in the process of the experiment. Then the first-order mass spectrum scanning was conducted, and the total ions and extracted ions were analyzed. According to the mass spectrum, total ion chromatogram and extracted ion flow diagrams from the three samples extracted at 5, 20, and 60 minutes. The mass-to-charge ratio of the main degradation products of ATZ was 128, 129, 146, 156, 172, 174, 188, 198, 214,218 , and 232. The relative molecular weight of ATZ is $216, \mathrm{~m} / \mathrm{z} 218$ has a molecular weight 2 greater than ATZ. Thus $\mathrm{m} / \mathrm{z} 218$ is produced when the methyl group is replaced by the hydroxyl group in the process of ATZ degradation, that is 2-chloro-4-diethylamino-6-hydroxyisopropyl atrazine, CDHA. 
m/z198 has a molecular weight 18 less than ATZ. Thus, in the process of ATZ degradation, $\mathrm{Cl}$ atoms are replaced by hydroxyl groups to produce 2-hydroxy-4-diethylamino-6-isopropylamino atrazine, HDIA. $\mathrm{m} / \mathrm{z} 156$ has a molecular weight 42 less than HDIA, which is the molecular weight of isopropyl. Thus, $\mathrm{m} / \mathrm{z} 156$ is regarded as the isopropyl product of HDIA, namely 2-hydroxy-4-diethylamino-6-amino atrazine, HDAA. m/z174 has a molecular weight 42 less than HDIA, which is the molecular weight of isopropyl. Thus, $\mathrm{m} / \mathrm{z} 174$ is regarded as isopropyl ATZ, namely 2-chloro-4-diethylamino-6-amino atrazine, CDAA. m/z188 has a molecular weight 28 less than HDIA, which is the molecular weight of ethyl. Thus, $\mathrm{m} / \mathrm{z} 188$ is regarded as desethyl ATZ, that is 2-chloro-4-amino-6-isopropylamino atrazine, CAIA. m/z146 has a molecular weight 28 less than HDIA, which is the molecular weight of ethyl. $\mathrm{m} / \mathrm{z} 146$ has a molecular weight 42 less than CAIA, which is the molecular weight of isopropyl. Thus $\mathrm{m} / \mathrm{z} 146$ is regarded as deethylated isopropyl ATZ, that is 2-chloro-4,6-diamino atrazine, CDA. m/z128 has a molecular weight 18 less than $\mathrm{m} / \mathrm{z} 146$ and 28 less than $\mathrm{m} / \mathrm{z} 156$. Thus $\mathrm{m} / \mathrm{z} 128$ is regarded as chlorine ions of CDA replaced by hydroxyl groups or deethyl product of HDAA, that is 2-hydroxy-4,6-diamino atrazine, HDA. m/z129 has a molecular weight 1 greater than HDA. Therefore, m/z129 was produced by HAD amidogen, which was replaced by hydroxy, namely 2,4-dihydroxy-6-amino atrazine, DAA. $\mathrm{m} / \mathrm{z} 232$ has a molecular weight 16 greater than ATZ, which is the molecular weight of hydroxy. Therefore, in the process of ATZ degradation, a hydrogen atom was replaced by a hydroxyl group to produce 2-Chloro-4-hydroxyethylamino-6-isopropyl atrazine, CHIA. m/z214 has a molecular weight 18 less than CHIA. Therefore, $\mathrm{m} / \mathrm{z} 214$ may be the product of the CHIA chloride ion being replaced by a hydroxyl group, that is 2-hydroxy-4-hydroxyethylamino-6-isopropyl atrazine, HHIA. It can, thus, be seen that the degradation of ATZ by US/PMS was mainly conducted by dealkylation, dechloridation, and hydroxylation, which are similar to the research results of Ji [20], Javed [23], Wu [46], and others. The degradation path of ATZ is shown in Figure 9.

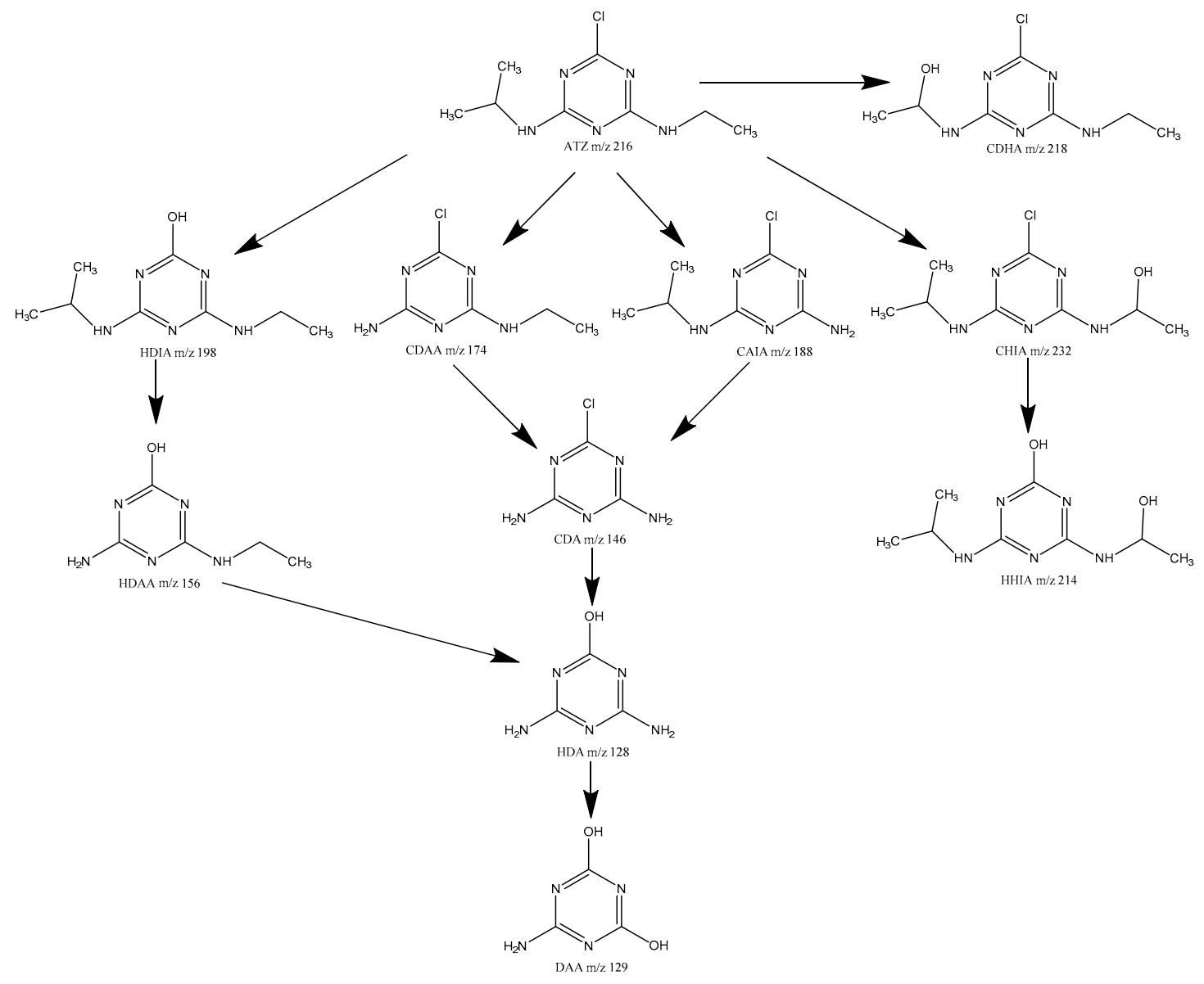

Figure 9. The possible degradation pathway of ATZ. 


\section{Conclusions}

In this research, the US/PMS based degradation of ATZ in phosphate buffer is investigated. The degradation mechanism, oxidation kinetics, and degradation products of ATZ by US/PMS are analyzed. The influences of reaction temperature, PMS concentration, ATZ concentration, $\mathrm{pH}$ value, and US intensity on the degradation efficiency of ATZ are discussed in detail. The main results are presented as follows. The higher the temperature is, the higher the degradation efficiency of US/PMS to ATZ is. The temperature variation within the normal temperature range $\left(10-25^{\circ} \mathrm{C}\right)$ has a significant effect on the efficiency of ATZ degradation by US/PMS. Within the range of existing experimental settings, the greater the concentration of PMS is, the greater the intensity of US, the higher the $\mathrm{pH}$ value is, and the higher the degradation efficiency of US/PMS on ATZ is. Since the concentration of ATZ in the reaction system increases gradually, the efficiency of ATZ degradation by US/PMS decreases continuously. US can activate PMS. $\mathrm{HO} \bullet$ and $\mathrm{SO}_{4}{ }^{-} \bullet$ coexist in the US/PMS system at the same time. The degradation of ATZ by US/PMS is dominated by free radical oxidation degradation. At a $\mathrm{pH}$ of 7 , US alone accounted for $29.29 \%$ of the total ATZ removal rate. $\mathrm{Cl}^{-}, \mathrm{HCO}_{3}{ }^{-}$, and $\mathrm{NO}_{3}{ }^{-}$showed inhibitory effect on the ATZ degradation by the US/PMS system under the concentration setting, and the inhibitory ability of the three ions was in the order of $\mathrm{Cl}^{-}, \mathrm{HCO}_{3}{ }^{-}$, and $\mathrm{NO}_{3}{ }^{-}$from large to small. The reaction kinetics of ATZ degradation by US/PMS was consistent with Quasi first order reaction kinetics. The degradation of ATZ by US/PMS was mainly realized by dealkylation, dechloridation, and hydroxylation, but the triazine ring was not degraded. A total of $10 \mathrm{ATZ}$ degradation intermediates were found by product analysis. The presented research has a high potential for the detoxification of water contaminated with atrazine.

Author Contributions: W.X. conceived and designed the experiments. Y.L. performed the experiments. Y.Z. analyzed the data. N.D. contributed reagents and analysis tools. J.Z. wrote the paper.

Acknowledgments: The Key Fund Project of Sichuan Provincial Department of Education [grant number 17ZB0031], the Science and Technology Project of Sichuan Province [grant number 2017GZ0375,2018JY0518], and the National Training Program of Innovation and Entrepreneurship for Undergraduates [grant number 201711116006] financially supported this study.

Conflicts of Interest: The authors declare no conflict of interest.

\section{References}

1. Li, Q.; Huang, G.; Wang, Y.; Liu, X. Advances of studies on ecological risk of herbicide atrazine and its determination and remediation. Chin. J. Appl. Ecol. 2002, 13, 625-628.

2. Meng, S.; Hu, G.; Qu, J.; Wei, W.; Chen, J. Research progress on atrazine residue in water environment and its toxicological effects. Environ. Pollut. Control 2009, 31, 64-68.

3. Jones, T.W.; Kemp, W.M.; Stevenson, J.C.; Means, J.C. Degradation of atrazine in estuarine water/sediment systems and soils. J. Environ. Qual. 1981, 11, 632-638. [CrossRef]

4. Comber, S.D.W. Abiotic Persistence of Atrazine and Simazine in Water. Pest Manag. Sci. 2015, 55, 696-702. [CrossRef]

5. William, R.; James, L.; Mary, F; Douglas, U. Reregistration Eligibility Science Chapter for Atrazine Environmental Fate and Effects Chapter. In Report of Environmental Fate and Effects Revised Risk; US Environmental Protection Agency: Washington, DC, SUA, 2002.

6. Jin, R.; Ke, J.; Zhou, H. The Concentration and Source of Atrazine Residue in Water of Guanting Reservoir. Chin. J. Environ. Sci. 2002, 23, 126-128.

7. Hongyuan, L.I.; Hong, M.A.; Tao, B. Ecological risk assessment of atrazine and control strategy. J. Northeast Agric. Univ. 2006, 37, 552-556.

8. Yan, D.H.; Yan, H.E.; Wang, H. Environmental Characteristics of the Atrazine in the Waters in East Liaohe River Basin. Environ. Sci. 2005, 26, 203-208.

9. Yang, M.; Zhou, F.; Sun, C. Residual characteristics and sources of toxic organic pollutants in jiangsu section of Yangtze river. Environ. Chem. 2006, 25, 376-378.

10. Standards of Drinking Water: GB 5749e2006; Standards Press of China: Beijing, China, 2006. 
11. Walker, B.S.; Kramer, A.G.; Lassiter, C.S. Atrazine affects craniofacial chondrogenesis and axial skeleton mineralization in zebrafish (Danio rerio). Toxicol. Ind. Health 2018, 34, 329-338. [CrossRef]

12. Hayes, T.B.; Collins, A.; Lee, M.; Mendoza, M.; Noriega, N.; Stuart, A.A.; Vonk, A. Hermaphroditic, demasculinized frogs after exposure to the herbicide atrazine at low ecologically relevant doses. Proc. Natl. Acad. Sci. USA 2002, 99, 5476-5480. [CrossRef]

13. Lin, J.; Li, H.-X.; Qin, L.; Du, Z.-H.; Xia, J.; Li, J.-L. A novel mechanism underlies atrazine toxicity in quails (Coturnix Coturnix coturnix): Triggering ionic disorder via disruption of ATPases. Oncotarget 2016, 7, 83880. [CrossRef]

14. Sanderson, J.T.; Seinen, W.; Giesy, J.P.; van den Berg, M. 2-Chloro-s-triazine herbicides induce aromatase (CYP19) activity in H295R human adrenocortical carcinoma cells: A novel mechanism for estrogenicity? Toxicol. Sci. 2000, 54, 121-127. [CrossRef]

15. Ma, L.; Chen, S.; Yuan, J.; Yang, P.; Liu, Y.; Stewart, K. Rapid biodegradation of atrazine by Ensifer sp. strain and its degradation genes. Int. Biodeterior. Biodegrad. 2017, 116, 133-140. [CrossRef]

16. He, H.; Wu, B.; Yang, C. Effects of fulvic acids and electrolytes on colloidal stability and photocatalysis of nano- $\mathrm{TiO}_{2}$ for atrazine removal. Int. J. Environ. Sci. Technol. 2018, 1-10. [CrossRef]

17. Wu, X.; He, H.; Yang, W.L.; Yu, J.; Yang, C. Efficient removal of atrazine from aqueous solutions using magnetic Saccharomyces cerevisiae bionanomaterial. Appl. Microbiol. Biotechnol. 2018, 102, 7597-7610. [CrossRef]

18. Zhu, C.; Yang, W.L.; He, H.; Yang, C.; Yu, J.; Wu, X.; Zeng, G.; Tarre, S.; Green, M.J.C. Preparation, performances and mechanisms of magnetic Saccharomyces cerevisiae bionanocomposites for atrazine removal. Chemosphere 2018, 200, 380-387. [CrossRef] [PubMed]

19. Zhao, X.; Ouyang, W.; Hao, F.; Lin, C.; Wang, F.; Han, S.; Geng, X. Properties comparison of biochars from corn straw with different pretreatment and sorption behaviour of atrazine. Bioresour. Technol. 2013, 147, 338-344. [CrossRef] [PubMed]

20. Ji, Y.; Dong, C.; Kong, D.; Lu, J.; Zhou, Q. Heat-activated persulfate oxidation of atrazine: Implications for remediation of groundwater contaminated by herbicides. Chem. Eng. J. 2015, 263, 45-54. [CrossRef]

21. Gu, X.; Lu, S.; Qiu, Z.; Sui, Q.; Miao, Z.; Lin, K.; Liu, Y.; Luo, Q. Comparison of Photodegradation Performance of 1,1,1-Trichloroethane in Aqueous Solution with the Addition of $\mathrm{H}_{2} \mathrm{O}_{2}$ or $\mathrm{S}_{2} \mathrm{O}_{8}{ }^{2-}$ Oxidants. Ind. Eng. Chem. Res. 2012, 51, 7196-7204. [CrossRef]

22. Luca, A.D.; He, X.; Dionysiou, D.D.; Dantas, R.F.; Esplugas, S. Effects of bromide on the degradation of organic contaminants with UV and $\mathrm{Fe}^{2+}$ activated persulfate. Chem. Eng. J. 2016, 318, 206-213. [CrossRef]

23. Khan, J.A.; He, X.; Shah, N.S.; Khan, H.M.; Hapeshi, E.; Fatta-Kassinos, D.; Dionysiou, D.D. Kinetic and mechanism investigation on the photochemical degradation of atrazine with activated $\mathrm{H}_{2} \mathrm{O}_{2}, \mathrm{~S}_{2} \mathrm{O}_{8}{ }^{2-}$ and $\mathrm{HSO}_{5}{ }^{-}$. Chem. Eng. J. 2014, 252, 393-403. [CrossRef]

24. Lu, Y.; Ding, Z.; Zhang, J.; Fu, C.; Xia, X.; Fang, Y. Degradation of Atrazine by UV/PMS in Phosphate Buffer. Pol. J. Environ. Stud. 2019, 28, 2735-2744. [CrossRef]

25. Su, S.; Guo, W.; Yi, C.; Leng, Y.; Ma, Z. Degradation of amoxicillin in aqueous solution using sulphate radicals under ultrasound irradiation. Ultrason. Sonochem. 2012, 19, 469-474. [CrossRef]

26. Lutze, H.V.; Stephanie, B.; Insa, R.; Nils, K.; Rani, B.; Melanie, G.; Clemens, V.S.; Schmidt, T.C. Degradation of chlorotriazine pesticides by sulfate radicals and the influence of organic matter. Environ. Sci. 2015, 49, 1673-1680. [CrossRef]

27. Luo, C.; Ma, J.; Jiang, J.; Liu, Y.; Song, Y.; Yang, Y.; Guan, Y.; Wu, D. Simulation and comparative study on the oxidation kinetics of atrazine by $\mathrm{UV} / \mathrm{H}_{2} \mathrm{O}_{2}, \mathrm{UV} / \mathrm{HSO}_{5}{ }^{-}$and $\mathrm{UV} / \mathrm{S}_{2} \mathrm{O}_{8}{ }^{2-}$. Water Res. 2015, 80, 99-108. [CrossRef]

28. Hayon, E.; Treinin, A.; Wilf, J. Electronic spectra, photochemistry, and autoxidation mechanism of the sulfite-bisulfite-pyrosulfite systems. $\mathrm{SO}_{2}{ }^{-}, \mathrm{SO}_{3}{ }^{-}, \mathrm{SO}_{4}{ }^{-}$, and $\mathrm{SO}_{5}{ }^{-}$radicals. J. Am. Chem. Soc. 1972, 94, 47-57. [CrossRef]

29. Ghanbari, F.; Moradi, M. Application of peroxymonosulfate and its activation methods for degradation of environmental organic pollutants. Chem. Eng. J. 2017, 310, 41-62. [CrossRef]

30. Wang, J.L.; Xu, L.J. Advanced oxidation processes for wastewater treatment: Formation of hydroxyl radical and application. Crit. Rev. Environ. Sci. Technol. 2012, 42, 251-325. [CrossRef]

31. Anipsitakis, G.P.; Dionysiou, D.D. Radical generation by the interaction of transition metals with common oxidants. Environ. Sci. Technol. 2004, 38, 3705-3712. [CrossRef] 
32. Buxton, G.V.; Greenstock, C.L.; Helman, W.P.; Ross, A.B. Critical review of rate constants for reactions of hydrated electrons, hydrogen atoms and hydroxyl radicals $\left(\cdot \mathrm{OH} / \cdot \mathrm{O}^{-}\right.$in aqueous solution. J. Phys. Chem. Ref. Data 1988, 17, 513-886. [CrossRef]

33. Sun, J.; Li, X.; Feng, J.; Tian, X. Oxone/ $\mathrm{Co}^{2+}$ oxidation as an advanced oxidation process: Comparison with traditional Fenton oxidation for treatment of landfill leachate. Water Res. 2009, 43, 4363-4369. [CrossRef]

34. Zhou, J.; Xiao, J.; Xiao, D.; Guo, Y.; Fang, C.; Lou, X.; Wang, Z.; Liu, J. Transformations of chloro and nitro groups during the peroxymonosulfate-based oxidation of 4-chloro-2-nitrophenol. Chemosphere 2015, 134, 446-451. [CrossRef]

35. Yao, Y.; Chen, H.; Qin, J.; Wu, G.; Lian, C.; Zhang, J.; Wang, S. Iron encapsulated in boron and nitrogen codoped carbon nanotubes as synergistic catalysts for Fenton-like reaction. Water Res. 2016, 101, 281-291. [CrossRef]

36. Buxton, G.V.; Salmon, G.A.; Wood, N.D. A Pulse Radiolysis Study of the Chemistry of Oxysulphur Radicals in Aqueous Solution; Springer: Dordrecht, The Netherlands, 1990.

37. Huie, R.E.; Clifton, C.L. Temperature dependence of the rate constants for reactions of the sulfate radical, $\mathrm{SO}_{4}{ }^{-}$, with anions. J. Phys. Chem. 1990, 94, 8561-8567. [CrossRef]

38. Huang, J.; Mabury, S.A. A new method for measuring carbonate radical reactivity toward pesticides. Environ. Toxicol. Chem. Int. J. 2000, 19, 1501-1507. [CrossRef]

39. Jayson, G.; Parsons, B.; Swallow, A.J. Some simple, highly reactive, inorganic chlorine derivatives in aqueous solution. Their formation using pulses of radiation and their role in the mechanism of the Fricke dosimeter. J. Chem. Soc. Faraday Trans. 1 Phys. Chem. Cond. Phases 1973, 69, 1597-1607. [CrossRef]

40. Grigor'ev, A.; Makarov, I.; Pikaev, A. Formation of $\mathrm{Cl}_{2}{ }^{-}$in the bulk of solution during radiolysis of concentrated aqueous solutions of chlorides. Khimiya Vysokikh Ehnergij 1987, 21, 123-126.

41. Das, T.N. Reactivity and role of $\mathrm{SO}_{5}{ }^{\bullet-}$ radical in aqueous medium chain oxidation of sulfite to sulfate and atmospheric sulfuric acid generation. J. Phys. Chem. A 2001, 105, 9142-9155. [CrossRef]

42. Yu, X.-Y.; Barker, J.R. Hydrogen peroxide photolysis in acidic aqueous solutions containing chloride ions. II. Quantum yield of $\mathrm{HO \bullet (Aq)} \mathrm{radicals.} \mathrm{J.} \mathrm{Phys.} \mathrm{Chem.} \mathrm{A} \mathrm{2003,} \mathrm{107,} \mathrm{1325-1332.} \mathrm{[CrossRef]}$

43. Gao, Y.Q.; Gao, N.Y.; Deng, Y.; Yin, D.Q.; Zhang, Y.S. Degradation of florfenicol in water by UV/ $\mathrm{Na}_{2} \mathrm{~S}_{2} \mathrm{O}_{8}$ process. Environ. Sci. Pollut. Res. Int. 2015, 22, 8693-8701. [CrossRef]

44. Simonin, J.P. On the comparison of pseudo-first order and pseudo-second order rate laws in the modeling of adsorption kinetics. Chem. Eng. J. 2016, 300, 254-263. [CrossRef]

45. Feng, D.; Yu, H.; Deng, H.; Li, F.; Ge, C. Adsorption characteristics of norfloxacin by biochar prepared by cassava dreg: Kinetics, isotherms, and thermodynamic analysis. BioResources 2015, 10, 6751-6768. [CrossRef]

46. Wu, S.; Li, H.; Li, X.; He, H.; Yang, C. Performances and mechanisms of efficient degradation of atrazine using peroxymonosulfate and ferrate as oxidants. Chem. Eng. J. 2018, 353, 533-541. [CrossRef] 